\title{
EMPHASIZING SECURITY AND WRITING IN A CROSS-DISCIPLINARY COURSE FOR COMPUTER INFORMATION SYSTEMS AND BUSINESS LAW STUDENTS
}

\author{
Lorrie Willey, Western Carolina University, lwilley@email.wcu.edu \\ Barbara Jo White, Western Carolina University, whiteb@email.wcu.edu
}

\begin{abstract}
A cross-disciplinary class, with an emphasis on information security issues, such as Payment Card Industry Data Security Standards (PCI DSS) and trade secrets, the relevant law, and business writing, serves a myriad of purposes in providing students a glimpse at real-world operations. Integrating elective courses within the Computer Information Systems (CIS) and Business Administration and Law (LAW) majors served to recreate, to a degree, the nature of the interaction between professionals within a business organization. Adding written communication as an essential component to the class and emphasizing the need to proofread work, addresses employer demands for communication skills in college graduates.
\end{abstract}

Keywords: Cross-Disciplinary, Information Security, Proofreading, Writing, PCI DSS

\section{INTRODUCTION}

"This course is flexible and had some interesting topics for discussion. I like that it combined a Business Law course with a CIS course as there is a lot of legalities involved with CIS and most people do not realize it. This course increased my interest in IT Security and Compliance as a career."

Computer Information Systems Student

"Learned a lot about CIS having to do with law and how it connects."

Business Administration and Law Student

In business organizations, departments do not function in a vacuum, rather departments interact to address business demands and challenges (Association to Advance Collegiate Schools of Business, AASCB, 2002). A crossdisciplinary class can mimic, to some degree, the interactions that will take place in the workplace. Information systems and business law are well-suited disciplines to blend for a cross-disciplinary course. Collaborative research on PCI DSS (Willey \& White, 2013), trade secrets (Willey, Ford, White, \& Clapper, 2011), employee monitoring (Willey, White, Domagalski, \& Ford, 2012), and data breach notification (Ford, White \& White, 2015) was the impetus in the development of this course. Law influences the activities of information systems professionals, who will work closely with legal departments to ensure the protection of information within the organization. Linking the two disciplines in this course and developing the added layer of writing about issues and the resolutions to those issues for fictitious clients, gives students a sense of what will be expected in the professional workplace.

\section{LITERATURE REVIEW}

A cross-disciplinary course provides opportunities for students not found in discipline-specific courses and offers a unique experience for students. Combining the benefits of a cross-disciplinary class with an emphasis on writing enhances the development of the skills that the students need to succeed in college and in the workplace. Requiring student teams to respond to concerns of fictitious clients can aid in the development of the creativity needed to identify and analyze information (Emig, 1977). These skills are also what employers want in the workplace. 


\section{Issues in Information Systems}

Volume 20, Issue 2, pp. 38-46, 2019

The National Association of Colleges and Employers survey of employers found that "more than $70 \%$ of employers have consistently identified... written communication ability... as key resume attributes" (Mackes, 2017). Business school alumni have also rated communication skills as "highly important" in the workplace (AACSB, 2002, p. 19).

\section{Cross-Disciplinary Learning}

Cross-disciplinary learning has been shown to improve interpersonal skills and create "an increase in regard for interdependence" (Robinson and Schaible, 1995, p. 56). Such courses provide students with a glimpse of the realities of the business world. In the workplace, IT employees will not work in isolation; rather they will interact and exchange ideas and information with colleagues across departments, from human resources to legal. Moreover, the cross-disciplinary course structure can include other aspects of the work experience: working in groups, research, consulting, problem solving and verbal and written communication skills. This integration of two disciplines demonstrates how the disciplines are connected and how gaining knowledge of other disciplines supplements a student's own studies with his or her discipline (Docoffe, Tromley, \& Tucker, 2006).

Academia is often disparaged for the "silo" effect in that various disciplines may hold themselves distinct from others, thus failing to integrate knowledge (Russell, 1990). That also occurs in the classroom where knowledge introduced is often thought of as paramount and the interaction between disciplines minimized (AACSB, 2002). Students suffer from these artificial distinctions; in the workplace, graduates will interact with colleagues from all disciplines and will be called upon to solve problems that incorporate various disciplinary components (Ducoffe, et al., 2006). This more realistic representation of business relationships provides a connection between college studies and the professional life the students will encounter (McMurray \& Dutton, 2016). Students can begin to understand and make connections between what they study and what will be demanded from them in the workplace (McMurry \& Dutton, 2016). A cross-disciplinary class also serves to "blur boundaries" between disciplines, an activity that was recommended by the AACSB in a Task Force report in 2002 (AACSB, 2002, p. 20).

\section{Writing, Revising, and Proofreading}

Writing in and of itself is a form of learning and the process of putting words to paper serves to clarify and organize thoughts (Emig, 1977). This form of learning is important to all students. "Since words are our primary means of communicating, anyone who has not mastered their creative use is simply underprepared for any discipline, including STEM subjects" (Root-Bernstein, R. \& Root-Bernstein, M., 2011, para 2.)

Writing for a specific audience other than the teacher, which is the most common in college assignments, is essential in helping students write reports in a more real-world simulated setting (Melzer, 2009). Moreover, this form of writing is one that is specific to business or technical writing and one that is best introduced and supported within a class related to the discipline (Russell, 1990).

Verbal and written communication skills are important to employers and candidates displaying these skills are sought after (Peck \& Preston, 2017). In fact, when applying for employment, students may be compelled to provide potential employers with documentation of soft skills (Peck \& Preston, 2017). Of the top ten skills identified by employers, business writing was listed as second (Ghanaian, 2013). After entering the work force, students are often surprised by the level of writing required on the job and the importance of grammatically-correct, clear writing (Linville, 2015).

Client-based projects, the focus of the class assignments, demonstrated the link between the two disciplines and underscored the need to communicate information, regardless of discipline. This form of writing is often considered the "cornerstone" of a writing assignment (Seifert, 2009, p. 200). The need to resolve problems is, of course, embedded within the research and writing process of the assigned tasks and students were compelled to analyze and evaluate the information uncovered (Seifert, 2009). While the clients in this class were fictitious, their concerns represented real-world issues faced by organizations.

Moreover, for this cross-disciplinary class, the students created artifacts of their written communication skills in a form that complements the demands of the workplace. Use of a template provided a structure which demonstrated to students the basics regarding the type of writing that would be required in class and professionally: issue identification, analysis of business issues and recommendation of actions, and clear concise writing (Ghanndian, 2013). The report assignments allowed the students to use writing as a tool for learning information that would be 


\section{Issues in Information Systems}

Volume 20, Issue 2, pp. 38-46, 2019

relevant not just to their majors but to their future professional experiences (Melzer, 2009). Moreover, this form of writing is one that is specific to business or technical writing and one that is best introduced and supported within a class related to the discipline (Russell, 1990).

Requiring students to proofread their written work as the last step of the writing process and providing tools needed to assist them in this endeavor was an essential component of the writing assignments. It is often difficult to successfully proofread because reading and proofreading are not the same skill. When reading, the writer tends to consider the message she wanted to convey rather than what is actually written (Harris, 1987). Proofreading requires an attention to each word and each punctuation mark and the ability to verify whether the word or mark is needed and whether a different word or mark should be included (Harris, 1987). While students will hear the word, and have some understanding of the process it represents, proofreading is not intuitive and tools must be provided to assist in the development of this skill (Madraso, 1993).

\section{COURSE STRUCTURE}

The CIS students can take an elective course entitled "Special Topics: Information Security in Business," while the LAW students have the option to take an elective course entitled the "Legal Aspects of Managing Technology." Combining these two classes to form a cross-disciplinary class was a natural fit. These elective classes were scheduled at the same time and assigned adjoining classrooms. Students from both classes were divided into crossdisciplinary teams that had two students from the CIS major and two students from LAW major. These teams worked for a hypothetical company called "Technology Solutions" and responded to requests for information from potential fictitious clients.

Following a common introduction outlining a user-threat-vulnerability model (Plfeeger \& Plfeeger, 2012), the course units were covered in two-week time periods. The first class comprised a separate lecture for each discipline covering the topic in question from that discipline's point of view. The second class was a combined class to research the technical and legal topics. The third class was a combined class in which teams worked on their reports and/or created their presentations and the fourth class involved presentations. While all teams completed a request for information report for a fictitious client for each unit, each team presented on only two of the units. Instructors graded the written reports together to ensure consistency.

Activities for each new scenario presented within the course were conducted using a systematic approach: class review of client consulting sheet, group meetings to discuss research assignments, group work after research to discuss implications, drafting of concluding report using a provided template, generation of a Grammarly report, and finally, a simulated client meeting to present results and make recommendations. Grammarly in an online writing and grammar checker that was provided to the students. Various information security concerns, with both CIS and LAW implications, were the basis of the assigned modules representing fictitious clients. Included were: privacy as related to employee monitoring and technologies to accomplish employee-monitoring activities; software distribution and patent and copyright law as related to software code; trade secrets law and the physical and digital controls needed to maintain trade secrets within the organization; the requirements of PCI DSS within the credit card industry and the implementation of those standards within a payment system; and data breach controls and notification laws (Ford, et al., 2015). Research guidance and related readings were provided to the students as research assistance. Individual class lectures also provided information related to the research conducted by the group on behalf of the "Technology Solutions" clients. In the CIS section of the course, Gartner articles formed the basis for lectures related to different scenarios. For example, Garter articles on intellectual property and open source software (Driver, 2014) and moving to the latest version of PCI DSS standards (Litan and Kaur, 2014) were used in the course along with instruction on using Gartner Hype Cycles and Magic Quadrants. Other resources included CareerBuilder surveys on employee monitoring over time (Willey, et al., 2012), as well as a report on a Chinese espionage unit (Mandiant, 2013). As much as possible within the framework of the research projects, students were encouraged to look for, and classes noted, how current news reflected the research issue. 


\section{Issues in Information Systems \\ Volume 20, Issue 2, pp. 38-46, 2019}

\section{Scenario 1: Employee Monitoring, Social Media, and Monitoring Systems}

ManagExcellence (MGE) is a multi-national corporation that provides management consulting to companies around the globe. Formed in 1998, this corporation has a presence in all the major cities in the US and Europe. Strategic plans for the next decade include expansion into South America to tap into emerging markets in that part of the world. Companies depend on ManagExcellence to help them address business operations issues from strategic planning to acquisitions. Its 2500 employees are top notch and to keep it that way, and the hiring process for MGE is rigorous. The company is not just concerned with paper credentials, it wants to learn as much possible about its employees and potential employees so that the customers who have come to depend on excellent service and decision-making will not be disappointed and will continue to rely on MGE to assist in providing solutions for operations issues.

MGE's human resources team implemented the review of Facebook and LinkedIn social media for all potential hires. The interview process is threefold: potential applicants submit resumes and applications which are reviewed by human resources with a first, short interview. Applicants with outstanding resumes are contacted for a second interview. This interview is conducted by a committee including members of Human Resources as well as managers from the division in which the hire is to be placed. If the candidate successfully completes this interview, the candidate is asked for a third interview which is conducted by the manager of the division and members of the division selected by the manager. Prior to reporting for the third interview, however, the Human Resources team conducts its first background check. At this point, HR looks at three areas: criminal records, credit history and social media. To conduct these checks, HR asks the applicant to provide Social Security number and social media usernames and passwords. A candidate may choose not to provide the information, but, in that case, no further interviews will be conducted. If the requested information is provided, members of the HR staff conduct the background checks. If the applicant clears these checks, the third interview is scheduled. If that interview is successfully completed, HR will conduct its last candidate check by contacting former employers and/or references. Getting hired by MGE has its payoffs. Employees are very well compensated and receive numbers benefits from health insurance to pensions. The competition for jobs with MGE is fierce and MGE is in the position that it can choose to hire only the best.

However, to ensure quality and excellent service for customers, once hired, employees are closely monitored to ensure continued standards of excellence. MGE now wants to expand its employee monitoring to using systems to monitor social media for existing employees. MGE has many concerns: legal liability makes it essential to make sure employees are not making posts or comments in violation of law; the company wants to make sure that employees' internet presence is in line with company policy and expectations, and MGE wants to ensure that trade secrets and/or disparaging comments are not being posted by its employees. What are the legalities associated with using social media checks as part of the hiring process and to monitor employees? What systems can be used to conduct monitoring of social media site? Who should have access to the data collected through the monitoring process? How should MGE set this up? MGE has come to Technology Solutions for answers.

\section{Scenario 2: Intellectual Property, Software, and Distribution}

Oscar is an artist, a digital artist that is. While in college Oscar majored in IS and computer science and he knows his stuff. Even in college he was writing code and developing programs to help with his studies, as class projects and for fun. As a gamer, Oscar especially enjoyed developing games and decided early on in his college career that he was going to develop games professionally. Within a year after graduation, Oscar developed games that began to draw international interest, including Gale Force and Coming About. So far, Oscar has just given friends and family copies of his games but with the acclamation over the games, Oscar developed an online business from which he will sell his wares (Storm, Inc.). With these plans, he is starting to get worried about protecting his creator's interest in these games. He is not sure what he needs to do to protect his work and while Oscar knows that there are such things as copyrights and patents, he is not at all clear as to whether he should have a copyright or patent or what he needs to do to get one (Willey, White, \& Ford, 2010). He also is not sure whether his software is secure and he's not sure as to the best options for distributing his Gale Force and Coming About software through his company, Storm, Inc. Does he sell discs, have customers download the program, only have a mobile app, or just have customers use it through the cloud with subscribers? What are the IT security issues associated with software code and the various types of software distribution? Oscar has come to Technology Solutions for answers. 


\section{Issues in Information Systems}

Volume 20, Issue 2, pp. 38-46, 2019

\section{Scenario 3: Trade Secrets and Controls to Secure Trade Secrets}

About ten years ago, Jan gave up the work-a-day world to pursue his dream, brewing beer. It had been a hobby for many years and with support of family and friends, he struck out on his own to establish a microbrewery, Smokey Mountain Brews, in a college town in North Carolina. Success came quickly and Smokey Mountain Brews continues to be a top-rate brewery in the region. Over the past decade, his business has grown not only with established customers, but also with regional restaurants. Transporting beer, including his signature and awardwinning brew, Smokey Mountain Ale, to surrounding localities, including the city of Asheville, North Carolina and Knoxville, Tennessee, has been time-consuming and expensive. So, two years ago, Jan began planning to open a second brewery in Asheville, a city nationally known for its microbrews, and those plans are in the final stages. The facility is ready to go, equipment in place, and an assistant brew master hired. The problem, though, is that Jan is worried about maintaining the confidentiality of his brew recipes. Micro brewing is very competitive, and the success of his signature beers equates with the overall success of his brewery. Should his competitors produce a similar brew, his goodwill and market share will drop. His assistant brew master will have to know the recipes, so the possibility of these recipes getting out has weighed heavily on his mind. Jan met with his attorney and was advised that the best course of action was to secure the information as trade secrets. But what does that really mean for Jan? What does he need to do? How can he keep the new brew master from disclosing the recipes to others? How can Jan secure the systems in his business to ensure continued security of this data? How can systems limit who can access this information? Jan has come to Technology Solutions for answers (Willey, et al., 2011).

\section{Scenario 4: Requirements and Implementation of PCI DSS}

"Do you take credit cards?" the customer asked. That was a question the owners of Blue Mountain Jams were being asked over and over. Mary smiled, "Not yet but we are working on it. Hopefully, staring next month, we will." Once again, Mary wondered how much business they lost because they did not take credit cards. With the business growing, more and more people ask about paying by credit cards. $B M J$ is losing customers by not having that payment option. Located in the Blue Ridge Mountains of North Carolina, $B M J$ recording studio and retail store is the life ambition of the owners, John and Mary. Graduates of a local university with degrees in music and business, John and Mary have played the bluegrass scene in Western North Carolina and especially Asheville, since their high school years.

The success of the company is being inhibited by the need for customers to pay with cash or check. "John, that's another customer asking about credit cards," Mary said once the shop emptied out. "We have got to deal with this now." John nodded in agreement. The thought of taking on another major project for the business was intimidating. Starting the studio was an expensive and exhausting enterprise; acting as both musicians and business owners is demanding. John and Mary struggled to raise the funds to get the venture started and they knew that the step to credit cards was necessary to take the business to the next level. There is no question of BMJ's success; John and Mary's music knowledge and contacts in the local bluegrass music scene allows for the development of an extensive repertoire of country and bluegrass music. As well, $B M J$ has a positive reputation for preserving the traditional music of the mountains. Critical acclaim and financial success is great but not accepting credit cards is holding the business back. Like most small business owners, accepting credit cards was a step into the unknown. "I remember from an IS class that there are data security issues we would have to deal with and I am just not sure if our computer systems are set up for credit cards," John replied. "Karen next door told me that the credit card company had all sorts of security requirements and I have no idea what those policies are or how we can start the process for our business and employees. On top of that, she told me there is some crazy self-assessment we would have to do and she said it was way beyond her. Is accepting credit cards worth it? I guess it is time to find out." Later than afternoon, and feeling somewhat overwhelmed with the project, John calls a local business, Technology Solutions. You are assigned the task of uncovering the information John needs to answer his concerns and get $B M J$ answering "Do you take credit cards?" in the affirmative. John and Mary have come to Technology Solutions for answers (Willey \& White, 2013).

\section{Scenario 5: Data Breach, Incident Response, and Breach Notification}

ManagExcellence (MGE) is a multi-national corporation that provides management consulting to companies around the globe. Formed in 1998, this corporation has a presence in all the major cities in the US and Europe. Strategic plans for the next decade include expansion into South America to tap into emerging markets in that part of the world. Companies depend on ManagExcellence to help them address business operations issues from strategic planning to acquisitions. For operational purposes, including payment, MGE maintains personal customer data: 


\section{Issues in Information Systems}

Volume 20, Issue 2, pp. 38-46, 2019

names, addresses, business tax numbers, and individuals' social security numbers. This data is protected, or so MGE thought, but now a data breach has been discovered. MGE is not sure what or how much data has been breached but needs Technology Solutions to direct its course of action at this point to comply with legal mandates regarding data breaches. What does MGE need to do operationally with the IS department to stop the breach and position itself to securely maintain data? What obligations does MGE have to the customers whose data might now be exposed? MGE has come to Technology Solutions for answers (Ford, et al., 2015).

\section{Scenario 6: Poster Session}

Teams of CIS and LAW students created a poster covering technical and legal issues associated with one of the units above or a topic of their choice. The university print shop created posters from their submissions on corrugated plastic. A "Poster Session" was held in halls on the first floor the college of business with at least one student team member from CIS and LAW on hand to answer questions.

\section{STUDENT RESPONSE TO INSTRUCTION-METHODOLOGY}

Course evaluations were used to measure student reaction to instruction. In addition, a survey was used to measure student response to the course and attitudes toward writing and proofreading.

\section{RESULTS}

Fifty-five surveys (see Figure 1 showing 11 items on the following page), were completed by the students in the cross-disciplinary course. The sample (see Table 1 below) contained more males $(67.3 \%)$ than females $(32.7 \%)$. Students were asked to identify how much they agreed or disagreed with the statement and rated each item using a 7-point Likert scale with "1" = "Strongly Agree" to "7" = "Strongly Disagree."

Table 1. Demographics

\begin{tabular}{|l|l|l|}
\hline \multicolumn{1}{|c|}{ Course } & \multicolumn{1}{|c|}{ Gender } & \multicolumn{1}{|c|}{$\begin{array}{c}\text { \# of Survey } \\
\text { Responses }\end{array}$} \\
\hline $\begin{array}{l}\text { Computer Information Systems } \\
\text { Special Topics: Information Security in Business }\end{array}$ & Female & 7 \\
\cline { 2 - 3 } $\begin{array}{l}\text { Business Administration and Law: Legal Aspects } \\
\text { of Managing Technology }\end{array}$ & Male & 20 \\
\cline { 2 - 3 } & Female & 11 \\
\hline
\end{tabular}

\section{Course Evaluations}

A one-sample t-test was used to determine whether the overall course evaluation scores for both sections of the cross-disciplinary course differed significantly from all previous course evaluation scores for both instructors. Even though the evaluation was for the first time the course was taught, the cross-disciplinary course evaluation score for the CIS section $(M=3.38)$ was significantly higher than course evaluations for all other CIS classes taught by that instructor $(M=3.16, \mathrm{SD}=0.34), t(29)=2.045, p<.001)$. The evaluation score for the LAW section of the crossdisciplinary class $(M=3.40)$ was higher than that for the CIS section but not significantly higher than for previous LAW sections taught by the same instructor $(M=3.47, \mathrm{SD}=0.34), t(60)=2.000, p=.130)$.

\section{Student Perceptions About Writing}

A one-sample t-test was conducted to determine student perceptions about writing. Compared to the neutral value, students liked writing $(t(54)=-3.188, p=.002)$, believed they were good writers $(t(54)=-6.233, p<.000)$, and believed that their major classes $(t(54)=-2.689, p=.010)$ and careers $(t(53)=-4.078, p<.000)$ required a lot of writing.

With respect to gender, according to an independent samples t-test, female students believed they were good writers $(M=2.28, S D=1.18)$ more often than their male counterparts $(M=3.11, S D=1.41, t(53)=-2.158, p=.036)$. Although female students liked writing $(M=2.61, S D=1.38)$ more than male students did $(M=3.57, S D=1.82)$, results were not statistically significant $(t(53)=-1.969, p=.054)$. There were differences between CIS students' and 
non-CIS students' perceptions about writing. For example, non-CIS students believed their major classes required a lot of writing $(M=2.71, S D=1.30)$ compared to CIS students $(M=4.07, S D=1.82, t(53)=-3.200, p=.002)$.

Perceptions about Writing

$\begin{array}{ccccccc}1= & & & & 7= \\ \begin{array}{c}\text { Strongly } \\ \text { Agree }\end{array} & 2 & 3 & \begin{array}{c}4= \\ \text { Neither }\end{array} & 5 & 6 & \begin{array}{c}\text { Strongly } \\ \text { Disagree }\end{array}\end{array}$

\begin{tabular}{|c|c|c|c|c|c|c|c|c|}
\hline I like writing & $\begin{array}{c}10 \\
(18.2 \%) \\
\end{array}$ & $\begin{array}{c}13 \\
(23.6 \%) \\
\end{array}$ & $\begin{array}{c}5 \\
(9.1 \%) \\
\end{array}$ & $\begin{array}{c}16 \\
(29.1 \%)\end{array}$ & $\begin{array}{c}6 \\
(10.9 \%) \\
\end{array}$ & $\begin{array}{c}1 \\
(1.8 \%)\end{array}$ & $\begin{array}{c}4 \\
(7.3 \%)\end{array}$ & \\
\hline $\begin{array}{l}\text { My major classes } \\
\text { require a lot of } \\
\text { writing }\end{array}$ & $\begin{array}{c}8 \\
(14.5 \%)\end{array}$ & $\begin{array}{c}12 \\
(21.8 \%)\end{array}$ & $\begin{array}{c}10 \\
(18.2 \%)\end{array}$ & $\begin{array}{c}10 \\
(18.2 \%)\end{array}$ & $\begin{array}{c}9 \\
(16.4 \%)\end{array}$ & $\begin{array}{c}3 \\
(5.5 \%)\end{array}$ & $\begin{array}{c}3 \\
(5.5 \%)\end{array}$ & \\
\hline $\begin{array}{l}\text { My career requires a } \\
\text { lot of writing }\end{array}$ & $\begin{array}{c}9 \\
(16.4 \%) \\
\end{array}$ & $\begin{array}{c}12 \\
(21.8 \%) \\
\end{array}$ & $\begin{array}{c}8 \\
(14.5 \%) \\
\end{array}$ & $\begin{array}{c}14 \\
(25.5 \%)\end{array}$ & $\begin{array}{c}8 \\
(14.5 \%) \\
\end{array}$ & $\begin{array}{c}3 \\
(5.5 \%)\end{array}$ & $\begin{array}{c}0 \\
(0.0 \%)\end{array}$ & $=$ \\
\hline I'm a good writer & $\begin{array}{c}7 \\
(12.7 \%)\end{array}$ & $\begin{array}{c}22 \\
(40.0 \%)\end{array}$ & $\begin{array}{c}9 \\
(16.4 \%)\end{array}$ & $\begin{array}{c}10 \\
(18.2 \%)\end{array}$ & $\begin{array}{c}5 \\
(9.1 \%)\end{array}$ & $\begin{array}{c}1 \\
(1.8 \%)\end{array}$ & $\begin{array}{c}1 \\
(1.8 \%)\end{array}$ & \\
\hline
\end{tabular}

Perceptions about Proofreading and Revision

\begin{tabular}{|c|c|c|c|c|c|c|c|c|}
\hline $\begin{array}{l}\text { I typically revise my } \\
\text { papers at least once }\end{array}$ & $\begin{array}{c}13 \\
(23.6 \%)\end{array}$ & $\begin{array}{c}18 \\
(32.7 \%)\end{array}$ & $\begin{array}{c}11 \\
(20.0 \%)\end{array}$ & $\begin{array}{c}5 \\
(9.1 \%)\end{array}$ & $\begin{array}{c}1 \\
(1.8 \%)\end{array}$ & $\begin{array}{c}5 \\
(9.1 \%)\end{array}$ & $\begin{array}{c}1 \\
(1.8 \%)\end{array}$ & \\
\hline $\begin{array}{l}\text { Before using } \\
\text { Grammarly, I would } \\
\text { proofread most of my } \\
\text { papers }\end{array}$ & $\begin{array}{c}13 \\
(23.6 \%)\end{array}$ & $\begin{array}{c}18 \\
(32.7 \%)\end{array}$ & $\begin{array}{c}7 \\
(12.7 \%)\end{array}$ & $\begin{array}{c}10 \\
(18.2 \%)\end{array}$ & $\begin{array}{c}5 \\
(9.1 \%)\end{array}$ & $\begin{array}{c}0 \\
(0.0 \%)\end{array}$ & $\begin{array}{c}2 \\
(3.6 \%)\end{array}$ & \\
\hline $\begin{array}{l}\text { Proofreading is } \\
\text { important }\end{array}$ & $\begin{array}{c}24 \\
(43.6 \%) \\
\end{array}$ & $\begin{array}{c}11 \\
(20.0 \%) \\
\end{array}$ & $\begin{array}{c}8 \\
(14.5 \%) \\
\end{array}$ & $\begin{array}{c}8 \\
(14.5 \%) \\
\end{array}$ & $\begin{array}{c}1 \\
(1.8 \%)\end{array}$ & $\begin{array}{c}1 \\
(1.8 \%)\end{array}$ & $\begin{array}{c}2 \\
(3.6 \%) \\
\end{array}$ & \\
\hline $\begin{array}{l}\text { Before using } \\
\text { Grammarly, } \\
\text { proofreaders helped } \\
\text { me catch spelling } \\
\text { errors }\end{array}$ & $\begin{array}{c}8 \\
(14.5 \%)\end{array}$ & $\begin{array}{c}8 \\
(14.5 \%)\end{array}$ & $\begin{array}{c}16 \\
(29.1 \%)\end{array}$ & $\begin{array}{c}13 \\
(23.6 \%)\end{array}$ & $\begin{array}{c}2 \\
(3.6 \%)\end{array}$ & $\begin{array}{c}5 \\
(9.1 \%)\end{array}$ & $\begin{array}{c}3 \\
(5.5 \%)\end{array}$ & \\
\hline $\begin{array}{l}\text { It is difficult for me } \\
\text { to proofread my own } \\
\text { papers }\end{array}$ & $\begin{array}{c}4 \\
(7.3 \%)\end{array}$ & $\begin{array}{c}4 \\
(7.3 \%)\end{array}$ & $\begin{array}{c}15 \\
(27.3 \%)\end{array}$ & $\begin{array}{c}9 \\
(16.4 \%)\end{array}$ & $\begin{array}{c}11 \\
(9.1 \%)\end{array}$ & $\begin{array}{c}6 \\
(10.9 \%)\end{array}$ & $\begin{array}{c}6 \\
(10.9 \%)\end{array}$ & \\
\hline $\begin{array}{l}\text { Before using } \\
\text { Grammarly, I } \\
\text { typically couldn't find } \\
\text { someone to proofread } \\
\text { for me }\end{array}$ & $\begin{array}{c}6 \\
(10.9 \%)\end{array}$ & $\begin{array}{c}2 \\
(3.6 \%)\end{array}$ & $\begin{array}{c}11 \\
(9.1 \%)\end{array}$ & $\begin{array}{c}13 \\
(23.6 \%)\end{array}$ & $\begin{array}{c}10 \\
(18.2 \%)\end{array}$ & $\begin{array}{c}4 \\
(7.3 \%)\end{array}$ & $\begin{array}{c}9 \\
(16.4 \%)\end{array}$ & \\
\hline $\begin{array}{l}\text { Using Grammarly } \\
\text { improves the quality } \\
\text { of the papers I write }\end{array}$ & $\begin{array}{c}12 \\
(21.8 \%)\end{array}$ & $\begin{array}{c}14 \\
(25.5 \%)\end{array}$ & $\begin{array}{c}11 \\
(20.0 \%)\end{array}$ & $\begin{array}{c}9 \\
(16.4 \%)\end{array}$ & $\begin{array}{c}4 \\
(7.3 \%)\end{array}$ & $\begin{array}{c}2 \\
(3.6 \%)\end{array}$ & $\begin{array}{c}2 \\
(3.6 \%)\end{array}$ & \\
\hline
\end{tabular}

Figure 1. Frequency Responses for Writing Items in Cross-Disciplinary Course

\section{Student Perceptions About Proofreading}

A one-sample t-test was conducted to determine student perceptions about proofreading. Compared to the neutral value, students thought proofreading was important $(t(54)=-7.968, p<.000)$, and would, before using Grammarly, proofread most of their own papers $(t(54)=-6.234, p<.000)$, revise them at least once $(t(53)=-6.160, p<.000)$, and thought Grammarly improved the quality of the papers they wrote $(t(54)=-5.180, p<.000)$. Students also agreed that before Grammarly, proofreaders helped catch spelling errors $(t(53)=-4.078, p<.000)$. However, students neither agreed nor disagreed that it was difficult for them to proofread their own papers $(t(54)=0.477, p<$ $.635)$, or that before using Grammarly, they typically couldn't find someone to proofread for them $(t(54)=0.893, p$ $=.376)$. 


\section{Issues in Information Systems}

Volume 20, Issue 2, pp. 38-46, 2019

With respect to gender, independent samples t-tests showed there were no statistically significant differences. However, with respect to CIS students and non-CIS students, the non-CIS students believed that, before Grammarly, proofreaders helped catch spelling errors $(M=2.90, S D=1.45)$ more than CIS students did $(M=3.85, S D=1.73$, $t(53)=2.235, p=.030)$. There were no statistically significant differences related to other proofreading items.

\section{CONCLUSION}

Anecdotally, when registering for classes, students were not necessarily aware that the CIS security course was linked to a LAW elective. Initially, students didn't see the connections between the two disciplines. While the scenarios represented the security issues and topics that CIS students anticipated, the added layer of the legal obligations associated with those issues was unexpected. However, by the end of the semester, after working in their cross-disciplinary teams and conducting research from both perspectives, students were able see the connections between the disciplines more clearly.

In terms of the reports written for the class, overall, students thought that there were too many writing assignments. In retrospect, perhaps they were correct. Students also mentioned that they would have liked more time in groups to share their research and to consider the recommendations for the fictitious clients. Taking the student comments into consideration, a future version of the cross-disciplinary course could include four security-based consulting scenarios along with the concluding poster presentation. This would allow for more class time which could then be allocated for additional consultations.

While CIS and LAW were a natural fit for a cross-disciplinary course, similar courses, associated with other disciplines, could be developed. For example, CIS and accounting or finance disciplines would be a good fit to explore topics such as whistleblowing, financial data security, and audits. CIS and management, human resources, or marketing could also explore a variety of topics. In fact, there are few disciplines that would not provide opportunities for CIS students to explore the inter-disciplinary and inter-departmental connections that they will experience in the workplace.

\section{REFERENCES}

Association to Advance Collegiate Schools of Business (AACSB), (2002). Management education at risk: A Report from the Management Education Task Force, executive summary. Available: https:/www.aacsb.edu//media/aacsb/publications/research-reports/management-educationrisk.ashx?la=en\&hash=12EC81ADC64B3A582C09A87EAEA0043AA3011D4A

Docoffe, S.J., Tromley, C.L., \& Tucker, M. (2006). Interdisciplinary, team-taught, undergraduate business courses: The impact of integration. Journal of Management Education, 30(2), 276-294.

Driver, M. (2014). Examining the relationship between open source and intellectual property. Gartner, Inc. Available: https://www.gartner.com/en/documents/2802818

Emig, J. (1977). Writing as a mode of learning. College Composition and Communication, 28(2), 122-128.

Ford, J. C., White, B. J., \& White, K. M. (2015). After the data breach: Data breach notification laws and more. Issues in Information Systems, 16(4), 86-94.

Ghannadian, F. (2013). What employers want, what we teach. BizEd, March/April 2013. Available: https://bized.aacsb.edu/articles/2013/03/what-employers-want-what-we-teach

"Grammarly," Available: www.grammarly.com

Harris, J. (1987). Proofreading: A reading/writing skill. College Composition and Communication, 38(4), 464-466. 
Linville, C. (2015). Real world writing: What employers expect. Available: http://webpages.csus.edu/ sac16141/RealWorldWriting.pdf

Litan, A. \& Rajpreet, K. (2014). What's changing and how to respond to PCI v3.0. Gartner, Inc. Available: https://www.gartner.com/en/documents/2827818

Mackes, M. (2017). “Employer-Preferred Skills and Attributes.” In Peck, A. (Ed.), Engagement and Employability Integrating career learning through cocurricular experiences in postsecondary education (xi-xxxi). Washington, DC: NASPA Inc.

Madraso, J. (1993). Proofreading: The skill we've neglected to teach. The English Journal, 82(2), 32-41.

Mandiant, A. P. T. (2013). Exposing one of China's cyber espionage units. Available https://www.fireeye.com/content/dam/fireeye-www/services/pdfs/mandiant-apt1-report.pdf

Melzer, D. (2009). Writing assignments across the curriculum: A national study of college writing. National Council of Teachers of English. Available: http://www.ncte.org/library/NCTEFiles/Resources/Journals/ccc/0612dec09/ccc0612writing.pdf

McMurray, S., \& Dutton, M. (2016). Employer demands from business graduates. Education and Training, 58(1), 112-132.

Peck, A., \& Preston, M. (2017). The value of engaged students, National Association of Colleges and Employers. Available: https://www.naceweb.org/career-readiness/competencies/the-value-of-engaged-students/

Pfleeger, C. P., \& Pfleeger, S. L. (2012). Analyzing computer security: A threat/vulnerability/countermeasure approach. Prentice Hall Professional.

Robinson, B., \& Schaible, R.M. (1995). Collaborative teaching: Reaping the benefits. College Teaching, 43(2), 5759.

Root-Bernstein, R. \& Root-Bernstein, M. (2011). Turning STEM into STREAM: Writing as an essential component of writing education. Available: https://www.nwp.org/cs/public/print/resource/3522

Russell, D. R. (1990). Writing across the curriculum: Historical perspective toward a social interpretation. College English, 52(1), 52-73.

Seifert, C. (2009). Writing for business: A graduate level course in problem-solving. Business Communication Quarterly, 72(2), 200-213.

Willey, L., White, B. J., Domagalski, T., \& Ford, J. C. (2012). Candidate-screening, information technology and the law: Social media considerations. Issues in Information Systems, 13(1), 300-309.

Willey, L., White, B. J., \& Ford, J.C. (2010). Software development and intellectual property: What you don't know can hurt you. Issues in Information Systems, 11(1), 77-84.

Willey, L. \& White, B.J. (2013) Teaching case: Do you take credit cards? Security and compliance for the credit credit card payment industry. Journal of Information Systems Education, 24(3), 181-188.

Willey, L., Ford, J. C., White, B. J. \& Clapper, D. L. (2011). Trade secret law and information systems: Can your students keep a secret?. Journal of Information Systems Education, 22(3), 271-278. 